\title{
CALON PRESIDEN DAN CALON WAKIL PRESIDEN INDONESIA SEBELUM DAN SESUDAH AMANDEMEN UNDANG-UNDANG DASAR NEGARA REPUBLIK INDONESIA TAHUN 1945
}

\author{
Al Fadhil \\ Pascasarjana Ilmu Hukum Universitas Lancang Kuning \\ Email: alfadhil_sh@yahoo.com
}

\section{Info Artikel:}

Diterima: 05 Maret 2020

| Disetujui: 01 Mei 2020

| Dipublikasikan: 30 Juni 2020

\begin{abstract}
Abstrak
Amandemen terhadap UUD 1945 yang telah dilalui empat tahap, mengakibatkan evolusi dari Persyaratan Calon Presiden dan Calon Wakil Presiden di Indonesia. Evolusi tersebut bisa berakibat fatal, yaitu dengan terbukanya peluang bagi Warga Negara Indonesia (WNI) Naturalisasi menuju Kursi Lembaga Kepresidenan, yang akan mengakibatkan tersingkirnya "Orang Indonesia Asli (Bumi Putra)" dari panggung politik di Negeri ini. Sedangkan Pasal 6 UUD 1945 dan selanjutnya berevolusi pasca beberapa tahapan amandemen hingga saat ini disebut dengan UUD NRI Tahun 1945 telah mengaturnya. Penelitian ini bertujuan untuk menganalisis proses Persyaratan Calon Presiden dan Calon Wakil Presiden di Indonesia, serta menganalisis perubahan Undang-Undang Dasar ( UUD ) 1945 Sebelum dan Sesudah Amandemen, dan idealnya persyaratan Calon Presiden dan Calon Wakil Presiden di Indonesia. Metode penelitian ini adalah hukum normatif. Hasil penelitiann ini adalah bahwa secara redaksional kata demi kata dalam Pasal 6 UUD NRI Tahun 1945 secara substansial hanya mensyaratkan calon presiden dan calon wakil presiden hanyalah seorang WNI dari kelahirannya menuju kursi kepresidenan di Republik Indonesia.
\end{abstract}

Kata Kunci: Presiden, Orang Indinesia Asli, UUD NRI Tahun 1945

\section{INDONESIAN PRESIDENT AND VICE PRESIDENTIAL CANDIDATES BEFORE AND AFTER LAW AMENDMENT STATE BASIS OF THE REPUBLIC OF INDONESIA YEAR 1945}

\begin{abstract}
The amendments to the 1945 Constitution which have been passed through four stages have resulted in the evolution of the Requirements for Presidential Candidates and Vice Presidential Candidates in Indonesia. This evolution can have fatal consequences, namely by opening up opportunities for Naturalized Indonesian Citizens (WNI) to become the Chair of the Presidential Institution, which will result in the elimination of "Original Indonesians (Bumi Putra)" from the political stage in this country. Meanwhile, Article 6 of the 1945 Constitution and its subsequent evolution after several stages of amendment until now referred to as the 1945 Constitution of the Republic of Indonesia has regulated it. This study aims to analyze the process of Requirements for Presidential and VicePresidential Candidates in Indonesia, as well as analyze the amendments to the 1945 Constitution (UUD) before and after the Amendment, and ideally the requirements for Presidential and VicePresidential Candidates in Indonesia. This research method is normative law. The results of this study are that word for word editorial in Article 6 of the 1945 Constitution of the Republic of Indonesia substantially only requires that the presidential and vice-presidential candidates are only Indonesian citizens from birth to the presidency in the Republic of Indonesia.
\end{abstract}

Keyword: President, Native Indonesians, Constitution of the Republic of Indonesia Year 1945 


\section{A. PENDAHULUAN}

Presiden dan Wakil Presiden Indonesia (atau secara bersama - sama disebut Lembaga Kepresidenan Indonesia) merupakan organ penting dalam perjalanan Sejarah Konstitusi di Negara Kesatuan Republik Indonesia (NKRI). Lembaga Kepresidenan Indonesia tersebut, terbentuk sehari setelah Republik Indonesia di Proklamirkan yakni 17 Agustus 1945. Lembaga Kepresidenan tersebut berlaku setelah di sahkannya Konstitusi Indonesia oleh Panitia Persiapan Kemerdekaan Indonesia (PPKI) tanggal 18 Agustus 1945. Konstitusi Indonesia yang disahkan PPKI dimaksud selanjutnya disebut Undang Undang Dasar (UUD) 1945, sebagai sumber hukum di NKRI.

Bicara tentang Lembaga Kepresidenan Indonesia berikut Konstitusi Indonesia sebagai aturan mainnya, merupakan mata rantai tak terpisahkan untuk menelisik para Tokoh pemegang tampuk Kekuasaan dalam hal menjalankan Konstitusi di Republik ini, sebagaimana diamanatkan Pasal 4 ayat (1) UUD 1945 untuk menduduki posisi tersebut ${ }^{1}$.

Merujuk pada Bab III UUD 1945 yang menjelaskan tentang syarat pemegang tampuk Kekuasaan Pemerintahan Negara, yakni Pasal 6 ayat (1) menyatakan:
"Presiden ialah orang Indonesia Asli"2. Menilik Amanat Konstitusi diatas, dapat disimpulkan bahwa; persyaratan Mutlak untuk menjadi seorang Calon Presiden dan Calon Wakil Presiden haruslah orang Indonesia asli (Bumi Putera).

Persyaratan mutlak Calon Presiden dan Calon Wakil Presiden tersebut pada akhirnya terjadi perubahan, sebagaimana amanat Pasal 6 ayat (1) Undang-Undang NRI Tahun 1945 pasca perubahan (Amandemen), di bunyikan bahwa; "Calon Presiden dan Calon Wakil Presiden adalah seorang Warga Negara Indonesia sejak Kelahirannya dan tidak pernah menerima Kewarganegaraan lain karena Kehendaknya Sendiri, tidak pernah mengkhianati Negara, serta mampu secara Rohani dan Jasmani untuk melaksanakan Tugas dan Kewajiban sebagai Presiden dan Wakil Presiden"3

Lebih jauh lagi disini perlu dijelaskan makna dari kata "Orang Indonesia Asli" itu sendiri ; menurut Bagir Manan sebutan Indonesia Asli merupakan keturunan langsung, pada Pasal 163 Indische Staatsregeling (IS) yang membedakan golongan pendudukan menjadi 3 golongan yaitu : golongan eropa yang dipersamakan, pendudukan golongan timur asing, dan pendudukan golongan orang indonesia asli 
atau yang lazim disebut Golongan Bumi Putera. $^{4}$

Adapun Pasal 131 IS, yang menentukan hukum yang berlaku untuk masing-masing golongan penduduk ditetapkan dalam pada Pasal 163 IS tersebut, lebih mencuatkan perbedaan kasta diantara 3 golongan yang dimaksud Pasal 163 IS. Ironisnya golongan bumi putera (orang Indonesia asli) dipandang rendah dari 2 golongan lainnya (sebutan inlander).

Pasca Pelantikan Achandra Tahar yang berujung pada pemberhentiannya dari Menteri Energi Sumber Daya dan Mineral akibat dari kewarganegaraan Gandanya dan juga Kewarganegaraan Amerika, kutip dari Geotimes.co.id Partai Persatuan Pembangunan barubaru ini merekomendasikan agar frasa “orang Indonesia asli" kembali dimasukkan dalam Pasal tersebut seperti sebelum diamandemen. ${ }^{5}$

Adapun mengenai definisi "orang Indonesia asli” yang dimaksud PPP adalah perorangan WNI yang berasal-usul dari suku atau ras yang berasal atau asli dari wilayah Indonesia. WNI yang memiliki darah atau keturunan asing dianggap PPP tidak bisa menjadi presiden atau wakil presiden. $^{6}$

Jika di teliti lebih jauh, persyaratan ini bukanlah Diskriminasi dan dikategorikan pelanggaran Ham, mengingat setiap Jabatan dan Pekerjaan lazimnya memiliki persyaratan tertentu, hingga Jabatan serta Pekerjaan itu dapat dilaksanakan secara Optimal. Namun adanya perubahan Redaksi pada kalimat Pasal tersebut, secara otomatis merubah Makna dan Prinsip Dasar serta Tujuan dari Pasal 6 ayat (1) UU NRI Tahun 1945 itu sendiri jika dibandingkan dengan Pasal dan ayat yang sama sebelum dilakukan Amandemen.

Menurut Sri Soemantri tentang Amandemen 1945 yang dilakukan beberapa waktu lalu "Baginya amandemen dilakukan sangat tergesagesa, meminimalkan partisipasi publik yang lebih luas", namun sebagai upaya meredam kritikan-kritikan tersebut, MPR membentuk Komisi Konstitusi melalui Ketetapan MPR No. II/MPR/2002 yang diikuti dengan Keputusan MPR No. 4/MPR/2003 tentang Susunan, Kedudukan,

4 Bagir Manan, Hukum Kewarganegaraan Indonesia Dalam UU No. 12 Tahun 2006. Tahun 2009. Hlm 16

5 Dikutip dari Media Geotimes.co.id, Miftakhul Huda, Tafsir Konsitusi Harus "Orang Indonesia Asli”, diakses Tgl 25 Juni 2019.

6 Loc.it 
Kewenangan dan Keanggotaan Komisi Konstitusi. $^{7}$

Sementara itu Wakil Presiden keenam Indonesia Try Sutrisno sempat bicara keras soal mantan Ketua MPR Amien Rais seperti yang dilansir dalam situs https/kumparan.com pada tanggal 22 September 2017 pada acara Silaturahmi Hari Tentara Nasional Indonesia, Try mengaku pernah mengingatkan Amien bahwa usulan melakukan amandemen UUD 1945 adalah sebuah langkah yang salah, "Waktu itu Amien Rais ketemu saya di sini (aula Gatot Soebroto), dia menyampaikan, 'Pakde enggak usah khawatir, enggak usah gelisah karena kita amandemen itu ada kesepakatan MPR-nya," ungkap Try. ${ }^{8}$

$$
\text { Amien Rais menanggapi }
$$

kekecewaan Try Sutrisno dan menyampaikan, beberapa hal positif dari amandemen yang dia lakukan. "Andai kata kita kembali UndangUndang Dasar '45 sebelum reformasi, itu presiden bisa dipilih berkali-kali tanpa bisa dibatasi," tuturnya. ${ }^{9}$

Selanjutnya, peryaratan Calon Presiden dan Calon Wakil Presiden

\footnotetext{
7 Kutipan dari Biografly.co.id, Sri Sumantri, Ilmuwan Hukum Tata Negara Indonesia, diakses tanggal 25 Juli 2019.

Kutipan dari kumparan.com, Try beberkan kekecewaan ke Amien Rais Soal Amandemen UUD 1945, diakses 25 Juli 2019.

9 Loc. It
}

dalam Pasal 6 ayat (2) UUD NRI Tahun 1945 hasil Perubahan Ketiga menyatakan; "Syarat-syarat untuk menjadi Presiden dan Wakil Presiden diatur lebih lanjut dengan UndangUndang".

Muladi mengatakan bahwa Percuma saja UUD 1945 diamandemen ratusan kali kalau tidak melibatkan rakyat. 1) Amandemen UUD 1945 jangan tergesa-gesa diusulkan karena konstitusi negara tidak bisa disamakan dengan anggaran dasar dan anggaran rumah tangga (AD/ART) sebuah partai atau ormas yang bisa diubah kapan saja. 2) konsitusi adalah fondasi bangsa. Jika sering di ubah-ubah malah akan menciptakan suasana yg tidak kondusif bagi perkembangan bangsa. Untuk mengamandemen UUD, memang tidak semudah membalik telapak tangan. 3) UUD adalah hukum tertinggi apabila diamandemen akan mempengaruhi stabilisasi produk hukum di bawahnya. Mengandemen UUD juga memerlukan biaya yang banyak. Jadi kenapa tidak kita efektifkan yang ada dulu. 4) UUD adalah jantungnya hukum apabila diubah akan mempengaruhi ketatanegaran negara kita dan stabilitas ekonomi, politik, sosial dan budaya bangsa.Yang terpenting adalah 
penyelenggaraan negara yang baik sekarang ini dengan aturan yang ada. ${ }^{10}$

Turunan dari amanat Konstitusi diatas diterangkan pada Pasal 570 UU Nomor 7 Tahun 2017 tentang Pemilihan Umum, adapun peraturan sebelumnya masih berlaku sepanjang tidak bertentangan dengan UU No. 7 Tahun 2017 tentang Pemilu diantaranya: (1) Undang-Undang Nomor 42 Tahun 2008 tentang Pemilihan Umum Presiden dan Wakil Presiden; (2) Undang-Undang Nomor 15 Tahun 2011 tentang Penyelenggara Pemilihan Umum, Tambahan Lembaran Negara Republik Indonesia Nomor 5246). ${ }^{11}$

Sementara Pasal 571, UU Nomor 7 Tahun 2017 tentang Pemilihan Umum menyatakan mencabut dan tidak memberlakukan: ${ }^{12} \quad$ (1) Undang-Undang Nomor 42 Tahun 2008 tentang Pemilihan Umum Presiden dan Wakil Presiden; (2) Undang-Undang Nomor 15 Tahun 2011 tentang Penyelenggara Pemilihan Umum.

Disisi lain, terjadinya perubahan makna substansi persyaratan Calon Presiden dan Calon Wakil Presiden

10 http://askarifandi.blogspot.com. Pro Kontra Amandemen UUD 1945, diakses tanggal 30 Juni 2019.

11 UU Nomor 15 Tahun 2011 tentang Penyelenggaraan Pemilihan Umum Umum

12 UU Nomor 7 Tahun 2017 tentang Pemilihan setelah beberapa kali Amandemen UUD NRI 1945, justru memberi celah berpindahnya tampuk Pemerintah Indonesia kepada masyarakat Indonesia warga Keturunan, baik dengan latar belakang Darah Campuran, terlebih lagi warga Negara Indonesia dengan Keturunan Asing akibat dari proses Migrasi kedua orangtuanya ke Indonesia mendapatkan Kewarganegaraan dari masa Kecilnya.

Persoalan mendasar yang berdampak fatal terhadap masa depan Negri dan Bangsa ini, yaitu dengan terpilihnya warga negara Keturunan Asing ataupun yang berdarah campuran menjadi Kepala Negara yang akan menentukan nasib Bumi Putera di Indonesia. Tanpa mengenyampingkan Sila Ketiga Pancasila, jika bangsa ini dipimpin oleh seseorang yang bukan Bumi Putera dikhawatirkan tak seperti yang diinginkan segenap lapisan masyarakat Indonesia akibat dari perbedaan latar belakang serta kultur dan budaya masyarakat Indonesia yang kental dengan adat ketimuran.

Disamping itu, terbukanya peluang bagi non Pribumi Asli Indonesia ataupun Bumi Putera menjadi pengelola Konstitusi di Republik ini, sangat rentan dengan resiko dengan akibat menjamurnya kepentingan Asing atau yang dewasa 
ini disebut dengan Antek Asing lalu di akomodir oleh kepentingan Politik Calon Presiden dan atau Calon Wakil Presiden yang terpilih dari pendatang Asing berkewarganegaraan Indonesia maupun warga negara berdarah campuran dimaksud.

\section{B. METODE PENELITIAN}

Metode yang digunakan dalam penelitian ini adalah yuridis normatif. Metode penelitian normatif disebut juga sebagai penelitian doktrinal (doctrinal reaserch) dengan Pendekatan yang digunakan yakni penelitian kualitatif (kualitatif research), yakni penelitian ini diarahkan kepada ekplorasi kajian pustaka (library research) yang bersifat statement atau pernyataan, sehingga penelitian ini bersifat deskriptif analitis. Deskriptif maksudnya penelitian dengan menggambarkan suatu peraturan hukum dalam konteks teori-teori hukum dan pelaksanaanya, serta menganalisis fakta secara cermat tentang sistem pemilihan Presiden dan Wakil Presiden di Indonesia.

\section{HASIL DAN PEMBAHASAN}

\section{Menurut Konstitusi Indonesia}

Mengacu pada cikal bakal Konstitusi Indonesia yang disahkan oleh Panitia Persiapan Kemerdekaan Indonesia (PPKI) pada tanggal 18 Agustus 1945, yang kelak disebut UUD 1945, periode ini dibagi lagi menjadi dua masa yaitu, pertama, antara 18 Agustus 1945-27 Desember1949 saat negara Indonesia berdiri sendiri, dan kedua antara 27 Desember 1949 - 15 Agustus 1950 saat negara Indonesia bergabung sebagai negara bagian dari negara federasi Republik Indonesia Serikat.

Undang-Undang Nomor 12 Tahun 2006 tentang Kewarganegaraan mendefinisikan "kewarganegaraan" sebagai "segala hal ikhwal yang berhubungan dengan warga negara" (Pasal 1 angka 2). Baik untuk keperluan praktis, apalagi keilmuan (ilmiah) rumusan semacam ini tidak berarti. Meskipun suatu definisi yang diberikan Undang-Undang Nomor 12 Tahun 2006 dapat dianalogikan dengan rumusan "kursi adalah segala hal ikhwal mengenai tempat duduk"13. Pengertian yang terlalu umum tersebut, masih memerlukan penyelidikan untuk mengetahui atau menemukan substansi "hal ikhwal yang berhubungan dengan kewarganegaraan". Untuk sekedar menemukan substansi walaupun tidak mungkin lengkap, karę̧a suatu definisi atau lukisan pengertian memang tidak pernah lengkap, maka dalam tulisan ini kewarganegaraan diartikan sebagai segala hal mengenai warga negara yang mencakup persoalan - persoalan tata cara menjadi warga negara, kehilangan kewarganegaraan, ketiadaan

\footnotetext{
13 UU No. 12 Tahun 2006 tentang Kewarganegaraan.
} 
kewarganegaraan, hak dan kewajiban warga negara, hubungan warga negara dan lain lain hal baik mengenai atau yang berhubungan dengan warga negara. ${ }^{14}$

\section{Ketetapan Majelis Permusyawaratan}

\section{Rakyat (MPR)}

\section{Ketetapan MPRS Nomor XX/MPRS/1966}

Ketetapan MPRS Nomor

XX/MPRS/1966 dibentuk pada masa awal pemerintahan Orde Baru. Tata urutan peraturan perundangan sebagaimana lampiran II Ketetapan MPRS Nomor XX/MPRS/1966 adalah sebagai berikut: ${ }^{15}$

a. Undang-Undang Dasar Republik Indonesia 1945

b. Ketetapan MPR

c. Undang-Undang/Peraturan

Pemerintah Pengganti UndangUndang

d. Peraturan Pemerintah

e. Keputusan Presiden

f. Peraturan-peraturan Pelaksanaan lainnya seperti:

- Peraturan Menteri

- Instruksi Menteri

- dan lain-lainnya

Tata urutan peraturan perundangundangan tersebut menimbulkan

14 Bagir Manan, SH.,M.C.L, Hukum Kewarganegaraan Indonesia dalam UU No. 12 Tahun 2016,;hlm.14

15 Ketetapan MPRS Nomor XX/MPRS/1966, tentang Tata Urutan Peraturan Perundangan pertanyaan, karena UUD 1945 dan Ketetapan MPR dibentuk oleh lembaga negara yang sama, tetapi kedudukan UUD 1945 lebih tinggi dari pada Ketetapan MPR.

MPR dalam menjalankan fungsi pertama mempunyai kedudukan lebih utama, MPR mempunyai kualitas sebagai konstituante, yaitu menetapkan UndangUndang Dasar yang hanya dilaksanakan apabila negara benar-benar menghendaki. Fungsi pertama ini tidak dilaksanakan secara teratur. Untuk fungsi kedua, pelaksanaannya secara teratur dalam jangka waktu lima Tahun sekali, yaitu ketika MPR bersidang. Penempatan Ketetapan MPR di bawah UUD 1945 selain ditinjau dari fungsi MPR, dapat pula ditinjau dari segi perubahananya. Untuk mengubah UndangUndang Dasar, syarat dan prosedurnya ditentukan dalam Undang-Undang Dasar itu sendiri, yaitu dalam Pasal 37, sedangkan untuk mengubah ataupun mencabut Ketetapan MPR tidak diperlukan syarat dan prosedur sebagaimana mengubah UndangUndang Dasar. Dengan adanya perbedaan kualitas fungsi-fungsi MPR, dilihat dari syarat dan prosedur perubahan UndangUndang Dasar dan Ketetapan MPR, maka menjadi jelas bahwa kedudukan UndangUndang Dasar 1945 sebagai Verfassungsnorm lebih tinggi dari pada Ketetapan MPR yang ditetapkan setiap lima Tahun sekali pada waktu MPR bersidang. 
Penempatan Ketetapan MPR dibawah UUD 1945 mempunyai konsekuensi bahwa materi muatan Ketetapan MPR harus sesuai atau tidak boleh bertentangan dengan UUD 1945, karena UUD 1945 merupakan sumber dan dasar dari pembentukan normanorma Ketetapan MPR. Fungsi Ketetapan MPR adalah merupakan pengaturan lebih lanjut hal-hal yang belum diatur di dalam UUD 1945, dan merupakan penjabaran lebih lanjut aturan-aturan yang ada dalam UUD 1945. Ditempatkannya Ketetapan MPR dalam tata urutan peraturan perundang-undangan dapat disimpulkan bahwa menurut Ketetapan MPRS Nomor XX/MPRS/1966, Ketetapan MPR termasuk peraturan perundang-undangan. Padahal apabila dikaji, tidak semua Ketetapan MPR materi muatannya bersifat pengaturan. Terdapat pula materi muatan Ketetapan MPR yang bersifat penetapan (beschikking), yang bersifat konkrit individual, misalnya Ketetapan MPR tentang pengangkatan Presiden dan Wakil Presiden.

\section{Ketetapan MPR Nomor}

\section{III/MPR/2000}

Ketetapan MPR Nomor III/MPR/2000 dibentuk ketika awal reformasi. Setelah runtuhnya pemerintahan Orde Baru yang dimulai dengan Sidang Istimewa MPR pada Tahun 1998 dan dilanjutkan dengan Sidang Umum MPR pada Tahun 1999, kemudian dilanjutkan dengan Sidang Tahunan MPR pada Tahun 2000, barulah MPR menetapkan Ketetapan MPR Nomor III/MPR/ $2000^{16}$ sebagai pengganti Ketetapan MPRS Nomor XX/MPRS/1966. Tata urutan peraturan perundang-undangan Republik Indonesia menurut Pasal 2 Ketetapan MPR Nomor III/MPR/2000 adalah berikut ini.

a. Undang-Undang Dasar 1945

b. Ketetapan Majelis Permusyawaratan Rakyat Republik Indonesia

c. Undang-Undang

d. Peraturan Pemerintah Pengganti Undang-Undang (Perpu)

e. Peraturan Pemerintah

f. Keputusan Presiden

g. Peraturan Daerah. Kedudukan Ketetapan MPR tidak mengalami perubahan, sama sebagaimana yang diatur di dalam Ketetapan MPRS Nomor XX/MPRS/1966.

\section{Undang-Undang Nomor 10 Tahun 2004}

Undang-Undang Nomor 10 Tahun 2004 tentang Pembentukan Peraturan Perundang-undangan ${ }^{17}$ dibentuk setelah UUD 1945 diamandemen dan setelah dibentuk Ketetapan MPR Nomor I/ MPR/2003 tentang Peninjauan Terhadap

\footnotetext{
${ }^{16}$ Ketetapan MPR Nomor III/MPR/2000, tentang Tata Urutan aturan perundang - undangan NRI

17 UU Nomor 10 Tahun 2004 tentang Jenis dan Hierarki aturan perundang-undangan
} 
Materi dan Status Hukum Ketetapan Majelis Pemusyawaratan Rakyat Sementara dan Ketetapan Mejelis Permusyawaratan Rakyat Republik Indonesia Tahun 1960 Sampai Dengan Tahun 2002. Jenis dan hierarki peraturan perundang-undangan menurut ketentuan Pasal 7 ayat (1) Undang - Undang Nomor 10 Tahun 2004 adalah berikut ini.

(a). Undang-Undang Dasar Negara Republik Indonesia Tahun 1945. (b). Undang-Undang/Peraturan Pemerintah Pengganti Undang-Undang. (c). Peratuan Pemerintah. (d). Peraturan Presiden. (e). Peraturan Daerah Undang-Undang Nomor 10 Tahun 2004 tidak mencantumkan Ketetapan MPR dalam jenis dan hierarki peraturan perundang-undangan. Hal ini disebabkan, ketika Undang-Undang Nomor 10 Tahun 2004 dibentuk, MPR tidak lagi berkedudukan sebagai lembaga tertinggi negara dan pelaksana penuh kedaulatan rakyat. MPR tidak berwenang mengeluarkan Ketetapan MPR yang bersifat mengatur. Produk hukum MPR yang bersifat pengaturan adalah ketika MPR melakukan perubahan terhadap UUD 1945.

\section{Undang-Undang Nomor 12 Tahun 2011}

Selanjutnya UU Nomor 10 Tahun 2004 tentang hierarki aturan perundangan undangan diubah dengan UU Nomor 12 Tahun 2011 tentang Hierarki aturan perundang - undangan pada Pasal 7 ayat (1) sebagai berikut ini. ${ }^{18}$

(a) Undang-Undang Dasar Negara Republik Indonesia Tahun 1945 (b). Ketetapan Majelis Permusyawaratan Rakyat 271 Vol. 21 No.2 Desember 2014 (c). UndangUndang/Peraturan Pemerintah Pengganti Undang-Undang (d). Peraturan Pemerintah (e). Peraturan Presiden (f). Peraturan

Daerah Provinsi (g). Peraturan Daerah Kabupaten/Kota

Ketetapan MPR masuk ke dalam jenis dan hierarki peraturan perundangundangan. Ketetapan MPR yang dimaksud di sini adalah Ketetapan MPRS dan Ketetapan MPR yang masih berlaku sebagaimana dimaksud dalam Pasal 2 dan Pasal 4 Ketetapan MPR Nomor I/MPR/2003. ${ }^{19}$

Pengaturan tata urutan peraturan perundang-undangan di Indonesia ditinjau dari ajaran Hans Kelsen mengenai "Stufenbau des Recht" atau "The hierarchy of law", Hans Kelsen tidak mengelompokkan norma-norma hukum perundang-undangan secara berjenjangjenjang. Kelsen hanya menyatakan bahwa setiap tata kaidah hukum merupakan suatu susunan dari pada kaidahkaidah. Dalam stufentheorie-nya Hans kelsen hanya mengemukakan bahwa di puncak

18 UU Nomor 12 Tahun 2011 tentang Hierarki Peraturan Perundangan - undangan.

19 Ketetapan MPR Nomor 1/MPR/2003 tentang Hierarki Peraturan Perundang - undangan. 
"stufenbau" terdapat kaidah yang fundamental yang disebut dengan "Grundnorm" yang bersifat abstrak, yang ditetapkan terlebih dahulu oleh masyarakat sebagai norma dasar yang merupakan gantungan bagi norma-norma yang berada di bawahnya. Grundnorm bersifat meta juridisc, bukan produk badan pembuat undang-undang, bukan bagian dari peraturan perundang-undangan, tetapi merupakan sumber dari semua sumber dari tatanan peraturan perundang-undangan yang berada di bawahnya.

Grundnorm dalam sistem hukum Indonesia adalah Pancasila yang merupakan sumber dari segala sumber hukum. Jika Hans Kelsen tidak mengemukakan secara rinci aturan hukum di bawah Grundnorm, sistem hukum Indonesia mengatur secara rinci aturan hukum yang berada di bawah Pancasila. $^{20}$

Pengaturan tata urutan atau hierarki peraturan perundang-undangan ditinjau dari teori Hans Nawiasky mengenai "De Lehre vom de Stufenbau der Rechtsordnung” atau "Die Stufenordnung der Rechtsnormen" bahwa susunan norma hukum terdiri dari Staatsfundamentalnorm

(Norma fundamental negara), Staatsgrundgesetz (Aturan Dasar Negara), Formell gesetz (undang-undang forml), dan Verordnung and autonome satzung (peraturan

20 Hans Kelsen, General Theory Law and State, New Work, Russell and Russell, 1944, hlm 112 pelaksanaan dan peraturan otonom), dalam norma hukum Indonesia menurut A. Hamid S. Attami telah dikelompokkan bahwa Staatsfundamentalnorm

(Norma fundamental negara) terdiri dari Pancasila dan Pembukaan UUD 1945, Staatsgrundgesetz (Aturan Dasar Negara) terdiri dari Batang Tubuh UUD 1945, Ketetapan MPR, dan Konvensi Ketatanegaraan, Formell gesetz (undangundang formal) yaitu Undang-Undang, dan Verordnung and autonome satzung secara hierarkis mulai dari Peraturan Pemerintah hingga Keputusan Bupati atau Walikota. ${ }^{21}$

Penempatan Pembukaan UUD 1945 dalam Staatsfundamentalnorm dan Batang Tubuh UUD 1945 dalam Staatsgrundgesetz karena Pembukaan UUD 1945 yang di dalamnya memuat rumusan Pancasila merupakan norma hukum tertinggi yang bersifat pre-supposed dan merupakan landasan filosofis.

Berbagai pengaturan mengenai tata urutan atau hierarki peraturan perundangundangan di atas, kedudukan Ketetapan MPR berada satu tingkat di bawah UndangUndang Dasar 1945 dan satu tingkat di atas Undang-undang/Peraturan Pemerintah Pengganti Undang-undang, kecuali di

${ }^{21}$ A. Hamid A. Attamimi, Peranan Keputusan Presiden Republik Indonesia dalam Penyelenggaraan Pemerintahan Negara; Suatu Studi Analisis Mengenai Keputusan Presiden yang Berfungsi Pengaturan dalam Kurun Waktu Pelita I-Pelita IV, Disertasi Ilmu Hukum Fakultas Pascasarjana Universitas Indonesia, Jakarta, 1990, hal.,287. 
dalam Undang-undang Nomor 10 Tahun 2004, Ketetapan MPR tidak dimasukkan ke dalam jenis dan hierarki peraturan perundang-undangan.

Keberadaan

Ketetapan MPR dalam jenis dan hierarki peraturan perundang-undangan tergantung pada keberadaan lembaga MPR itu sendiri. Perubahan Undang-Undang Dasar 1945 yang mengubah kedudukan lembaga MPR menjadi perdebatan ketika lembaganya berubah kedudukan dan kewenangannya, tetapi produk hukum yang dihasilkannya tidak berubah kedudukannya. Penempatan Ketetapan MPR yang bersamaan dengan Batang Tubuh UUD 1945 menurut A. Hamid S. Attamimi berdasarkan teori Hans Nawiasky di atas adalah pada saat itu MPR berkedudukan sebagai lembaga tertinggi negara dan pelaku sepenuhnya kedaulatan rakyat. Ketetapan MPR sebagaimana Batang Tubuh UUD 1945 merupakan Staatsgrundgesetz (Aturan Dasar Negara) yang berisi garis-garis besar atau pokokpokok kebijaksanaan negara. Norma hukum Ketetapan MPR berdasarkan teori HLA Hart merupakan norma hukum tunggal dan tidak dilekati dengan norma hukum sekunder. ${ }^{22}$ Penempatan Ketetapan MPR ke dalam jenis dan hierarki peraturan perundang-undangan sebagaimana diatur di dalam Undang-Undang Nomor 12 Tahun 2011 ternyata terabaikan, karena meskipun
Ketetapan MPR telah dimasukkan lagi ke dalam jenis dan hierarki peraturan perundangundangan dan ditempatkan lebih tinggi dari pada Undang-Undang/Peraturan Pemerintah Pengganti Undang-Undang, tetapi faktanya Ketetapan MPR belum dijadikan sebagai dasar hukum dalam pembentukan peraturan perundangundangan di bawah Ketetapan MPR, seperti dalam pembentukan Undang-Undang dan Peraturan Pemerintah Pengganti UndangUndang. Padahal salah satu makna herarki peraturan perundang-undangan adalah bahwa peraturan perundangundangan yang kedudukannya lebih tinggi dijadikan landasan atau dasar hukum bagi peraturan perundang-undangan yang lebih rendah atau dibawahnya, sehingga isi atau materi muatan peraturan perundang-undangan yang lebih rendah tidak boleh menyimpangi atau bertentangan dengan peraturan perundang-undangan yang lebih tinggi tingkatannya.

Sebelum UUD 1945 diamandemen, kedudukan MPR sebagai lembaga tertinggi negara mempunyai kekuasaan yang tidak terbatas. Kewenangan yang diberikan kepada MPR sebagai pelaksana penuh kedaulatan rakyat berdasarkan Pasal 3, Pasal 6 ayat (2) dan Pasal 37 UndangUndang Dasar $1945^{23}$ adalah berikut ini.
22 HLA Hart, Konsep Hukum (The Concept of Law). (Penerbit : Nusamedia Tahun 2013)
23 UUD 1945 
1. Majelis Permusyawaratan Rakyat menetapkan undang-undang dasar dan Garis-garis besar dari pada haluan negara (Pasal 3 UndangUndang Dasar 1945).

2. Presiden dan Wakil Presiden dipilih oleh Majelis

Permusyawaratan Rakyat dengan suara terbanyak. (Pasal 6 ayat (2) Undang-Undang Dasar 1945).

3. Untuk mengubah undang-undang dasar, sekurang-kurangnya 2/3 dari pada jumlah anggota Majelis Permusyawaratan Rakyat harus hadir. Putusan diambil dengan persetujuan sekurangkurangnya 2/3 daripada jumlah yang hadir. (Pasal 37 Undang-Undang Dasar 1945).

Setelah UUD 1945 diamandemen, Perubahan Pasal 1 ayat (2) mengubah sistem ketatanegaraan Indonesia dari supremasi MPR kepada sistem kedaulatan rakyat yang diatur melalui UUD Negara Republik Indonesia (NRI) Tahun 1945. ${ }^{24}$ Undang-Undang Dasar itulah yang menjadi dasar dan rujukan utama dalam menjalankan kedaulatan rakyat. Perubahan ketentuan Pasal 1 ayat (2) berimplikasi pada pengurangan kewenangan MPR. Kewenangan MPR yang berkurang adalah MPR tidak lagi berwenang memilih dan mengangkat Presiden dan Wakil Presiden, MPR tidak lagi berwenang menetapkan Garis-garis Besar Haluan Negara, dan MPR tidak diberikan kewenangan untuk mengeluarkan Ketetapan MPR yang bersifat mengatur.

Menurut Pasal 3 UUD 1945 setelah amandemen, kewenangan MPR adalah berikut ini. ${ }^{25}$

1. Mengubah dan menetapkan Undang-Undang Dasar

2. Melantik Presiden dan/atau Wakil Presiden

3. Memberhentikan Presiden dan/atau Wakil Presiden dalam masa jabatannya menurut UndangUndang Dasar. Berdasarkan kewenangan yang dimiliki tersebut, MPR bukanlah lembaga yang menjalankan kewenangannya secara rutin. Sifat perkerjaan MPR tidaklah bersifat tetap, melainkan bersifat ad hoc. Meskipun di atas kertas MPR itu sebagai lembaga negara memang terus ada, tetapi dalam arti yang aktual atau nyata, MPR itu sendiri sebenarnya baru dapat dikatakan ada (actual existence) pada saat kewenangan atau fungsinya sedang dilaksanakan (in action). 
Sifat pekerjaan MPR dikatakan ad hoc karena berdasarkan kewenangan yang dimilikinya, satu-satunya kewenangan MPR yang bersifat rutin dan dapat direncanakan adalah kegiatan persidangan untuk pelantikan Presiden dan Wakil Presiden setiap lima Tahunan.Sidang MPR untuk pelantikan Presiden dan Wakil Presiden itu sendiri bersifat fakultatif. Berdasarkan Pasal 9 ayat (1) dan ayat (2) Undang-Undang Dasar 1945, Sebelum memangku jabatannya, Presiden dan Wakil Presiden bersumpah menurut agama, atau berjanji dengan sungguh-sungguh di hadapan Majelis Permusyawaratan Rakyat atau Dewan Perwakilan Rakyat. Jika Majelis Permusyawaratan Rakyat atau Dewan Perwakilan Rakyat tidak dapat mengadakan sidang, Presiden dan Wakil Presiden bersumpah menurut agama, atau berjanji dengan sungguh-sungguh di hadapan pimpinan Majelis Permusyawaratan Rakyat dengan disaksikan oleh pimpinan Mahkamah Agung. Untuk kewenangan yang lain tidak bersifat tetap. Perubahan dan penetapan Undang-Undang Dasar tentunya hanya akan dilakukan oleh MPR sewaktu-waktu. Setelah perubahan empat kali berturut-turut pada Tahun 1999, Tahun 2000, Tahun 2001, dan Tahun 2002, masih akan lama untuk adanya perubahan lagi atas UUD 1945. Kita belum memperkirakan sampai waktu kapan akan ada lagiagenda perubahan atas UUD 1945.

Demikian pula dengan agenda pemberhentian Presiden dan/atau Wakil Presiden serta agenda pemilihan Presiden dan/atau Wakil Presiden untuk mengisi lowongan jabatan. Kita tidak dapat membuat ramalan mengenai kedua agenda ini akan dijalankan dalam waktu dekat.

\section{Aturan \\ Perundang-undangan \\ Persyaratan Calon Presiden dan Calon \\ Wakil Presiden}

Menurut UU No 42 Tahun 2008 tentang Pemilihan Umum Presiden dan Wakil Presiden sebagai berikut: ${ }^{26}$

Pertama, Bertakwa kepada Tuhan Yang Maha Esa. Kedua, Warga Negara Indonesia sejak kelahirannya dan tidak pernah menerima kewarganegaraan lain karena kehendaknya sendiri. Ketiga, Tidak pernah mengkhianati negara, serta tidak pernah melakukan tindak pidana korupsi dan tindak pidana berat lainnya. Keempat. Mampu secara rohani dan jasmani untuk melaksanakan tugas dan kewajiban sebagai Presiden dan Wakil Presiden. Kelima, Bertempat tinggal di wilayah Negara Kesatuan Republik Indonesia. Keenam, Telah melaporkan kekayaannya kepada instansi yang berwenang memeriksa laporan kekayaan penyelenggara negara. Ketujuh, Tidak sedang memiliki

26 UU No 42 Tahun 2008 tentang Pemilihan Umum Presiden dan Wakil Presiden. 
tanggungan utang secara perseorangan dan/atau secara badan hukum yang menjadi tanggung jawabnya yang merugikan keuangan negara. Kedelapan, Tidak sedang dinyatakan pailit berdasarkan putusan pengadilan. Kesembilan, Tidak pernah melakukan perbuatan tercela. Kesepuluh, Terdaftar sebagai Pemilih. Kesebelas, Memiliki Nomor Pokok Wajib Pajak (NPWP) dan telah melaksanakan kewajiban membayar pajak selama 5 Tahun terakhir yang dibuktikan dengan Surat Pemberitahuan Tahunan Pajak Penghasilan Wajib Pajak Orang Pribadi. Keduabelas, Belum pernah menjabat sebagai Presiden atau Wakil Presiden selama 2 (dua) kali masa jabatan dalam jabatan yang sama. Ketigabelas, Setia kepada Pancasila sebagai dasar negara, Undang-Undang Dasar Negara Republik Indonesia Tahun 1945, dan cita-cita Proklamasi 17 Agustus 1945. ${ }^{27}$ Keempatbelas, Tidak pernah dijatuhi pidana penjara berdasarkan putusan pengadilan yang telah mempunyai kekuatan hukum tetap karena melakukan tindak pidana yang diancam dengan pidana penjara 5 (lima) Tahun atau lebih. Kelimabelas, Berusia sekurang-kurangnya 35 (tiga puluh lima) Tahun. Keenambelas, Berpendidikan paling rendah tamat Sekolah Menengah Atas (SMA), Madrasah Aliyah (MA), Sekolah Menengah Kejuruan (SMK), Madrasah

27 UUD NRI Tahun 1945 .
Aliyah Kejuruan (MAK), atau bentuk lain yang sederajat. Ketujuhbelas, Bukan bekas anggota organisasi terlarang Partai Komunis Indonesia, termasuk organisasi massanya, atau bukan orang yang terlibat langsung dalam G.30.S/PKI. Kedelepanbelas, Memiliki visi, misi, dan program dalam melaksanakan pemerintahan negara Republik Indonesia.

Menurut Perubahan Ketiga UUD 1945 Pasal 6A, Presiden dan Wakil Presiden dipilih dalam satu pasangan secara langsung oleh rakyat melalui Pemilihan Umum Presiden dan Wakil Presiden (Pilpres). Sebelumnya, Presiden (dan Wakil Presiden) dipilih oleh Majelis Permusyawaratan Rakyat. Dengan adanya Perubahan UUD 1945, Presiden tidak lagi bertanggung jawab kepada MPR, dan kedudukan antara Presiden dan MPR adalah setara.

Calon Presiden dan Wakil Presiden diusulkan oleh partai politik atau gabungan partai politik peserta pemilu sebelumnya. Pilpres pertama kali di Indonesia diselenggarakan pada Tahun 2004.

Jika dalam Pilpres didapat suara $>50 \%$ jumlah suara dalam pemilu dengan sedikitnya $20 \%$ di setiap provinsi yang tersebar di lebih dari separuh jumlah provinsi Indonesia, maka dinyatakan sebagai Presiden dan Wakil Presiden terpilih. Jika tidak ada pasangan calon Presiden dan Wakil Presiden terpilih, maka pasangan yang memperoleh suara terbanyak pertama dan kedua dalam Pilpres 
mengikuti Pilpres Putaran Kedua. Pasangan yang memperoleh suara terbanyak dalam Pilpres Putaran Kedua dinyatakan sebagai Presiden dan Wakil Presiden Terpilih.

Secara harfiah, kata "daulat" dan "kedaulatan" berasal dari bahasa Arab "daulah" yang berarti rezim politik atau kekuasaan. $^{28}$ Kata ini sebagaimana disebutkan dalam Alquran. Arkar kata daulat dalam Alquran terkait dengan konsep mengenai kekuasaan di bidang politik dan kekuasaan di bidang ekonomi. Kata daulat ini kemudian diakulturasi ke dalam kosakata bahasa Indonesia yang diartikan sebagai "kekuasaan" atau "pemerintahan". Begitupun dengan kedaulatan $^{29}$ yang diartikan sebagai kekuasaan tertinggi atas suatu negara. Dengan demikian, kedaulatan atau sovereignty (souvereiniteit) merupakan konsep mengenai kekuasaan tertinggi dalam penyelenggaraan negara.

Pada tataran praktis, istilah kedaulatan sering diidentikkan dengan pengertian kekuasaan tertinggi dalam penyelenggaraan negara. Namun jika dikaitkan pada konteks jalannya pemerintahan suatu negara, pembahasan mengenai kedaulatan akan berujung pada pertanyaan prinsipil, apa dan siapa yang memegang kendali kekuasaan tertinggi dan

28 Jimly Asshiddiqie. Pokok-Pokok Hukum Tata Negara Indonesia Pasca Reformasi. Cetakan Kedua. (Jakarta: PT. Bhuana Ilmu Populer, 2008), hlm. 143. 29 Loc. It membuat keputusan akhir dalam kegiatan kenegaraan. Dalam kaitannya dengan ini, di dunia ilmu hukum danpolitik, dikenal adanya lima teori, yaitu (i) Teori Kedaulatan Tuhan; (ii) Teori Kedaulatan Raja; (iii) Teori Kedaulatan Negara; (iv) Teori Kedaulatan Rakyat; dan (v) Teori Kedaulatan Hukum. ${ }^{30}$

Secara historis, teori Kedaulatan Tuhan (The Sovereignty of God) merupakan teori yang paling tua. ${ }^{31}$ Teori ini memandang kekuasaan tertinggi itu dimiliki dan ada pada Tuhan. Tuhanlah yang merupakan sumber dari segala sumber kekuasaan. Namun dalam praktiknya, paham kedaulatan Tuhan ini biasanya dijelmakan dalam kekuasaan Raja atau Ratu yang berkuasa secara turun-temurun, sehingga Raja atau Ratu mendapatkan legitimasinya sebagai perkawilan kehendak Tuhan. Raja atau Ratu kemudian tidak merasa bertanggung jawab kepada siapapun kecuali kepada Tuhan. Akibatnya, kekuasaan Raja atau Ratu berubah menjadi mutlak, sehingga justru melahirkan ajaran baru tentang Kedaulatan Raja (The Sovereignty of the King).

Selanjutnya, berkembang pula teori Kedaulatan Negara (State"sSovereignty). Penganut ajaran kedaulatan negara ini

30 Jimly Asshiddiqie, 2008. Teori Kedaulatan. hlm. 144.

31 Yohanis Anton Raharusun. Daerah Khusus Dalam Perspektif NKRI (Telaah YuridisTerhadap Otonomi Khusus Bagi Provinsi Papua). (Jakarta: Konstitusi Press, 2009), hlm. 44. 
memandang bahwa kedaulatan itu tidak ada pada Tuhan begitupun pada Raja, tetapi kedaulatan berada pada negara. Sebab, negaralah yang menciptakan aturan, jadi segala sesuatu harus tunduk padanya sebagai regulator. Negara di sini dianggap sebagai suatu keutuhan yang menciptakan peraturan-peraturan hukum dan tidak ada satupun hukum yang berlaku jika tidak dikehendaki oleh negara.

Teori kedaulatan ini juga dikemukakan oleh George Jellinek yang pada pokoknya memandang kedaulatan merupakan penjelmaan daripada kehendak atau kemauan negara. Di luar negara, tidak ada satupun yang dapat menciptakan hukum. Dengan demikian, hukum tidak tertulis yang bukan dibuat oleh negara tetapi nyata-nyata berlaku dalam masyarakat (adat kebiasaan), tidaklah merupakan hukum. Lebih lanjut menurut Jellinek, adat kebiasaan itu hanya dapat menjadi hukum, apabila sudah ditetapkan oleh negara sebagai hukum. ${ }^{32}$

Namun gagasan kedaulatan negara kemudian diperhadapkan pada paham kedaulatan hukum (the Sovereignty of Law) yang memandang bahwa yang berdaulat itu bukanlah negara, melainkan hukumlah yang berdaulat. Sebab, baik Raja, penguasa, masyarakat, bahkan negara sekalipun,

32 Dikutip dari

http://nikmatperdamaian.blogspot.com. Diakses pada tanggal 26 Juli 2019 semua tunduk pada hukum. Semua sikap dan tingkah laku harus sesuai atau berdasarkan hukum. Sebagaimana yang dikemukakan Krabbe bahwa yang berdaulat itu adalah hukum. ${ }^{33}$

Seiring berkembangnya pemikiran hukum, paham kedaulatan rakyat pun mendapat tempatnya tersendiri. Teori Kedaulatan Rakyat (Sovereignty of thePeople) kemudian hadir sebagai bentuk perlawanan rakyat atas kekuasaan yang semakin absolut. Seperti dalam istilah "Demokrasi" yang berasal dari kata demos (rakyat) dan kratien atau kratos (kekuasaan). Paham ini memandang posisi rakyat sebagai penentu akhir penyelenggaraan kekuasaan negara. Titik tolak demokrasi adalah pada premis bahwa partisipasi rakyat yang sebesar-besarnya diperlukan dalam menjalankan penyelenggaraan negara. Sebab, dalam prinsipyang menjadi dasar bagi penyelenggaraan kekuasaan negara disanggah oleh prinsip demokrasi, yaitu: dari, oleh, dan untuk rakyat. ${ }^{34}$

Namun setali tiga uang dengan paham kedaulatan lainnya, paham kedaulatan rakyat inipun selalu menghadapi antinominya sendiri, yaitu antara demos dan nomos. Dalam pandangan Jimly, nomos

33 Dikutip http://kampushukum.com/teorikedaulatan hukum. Diakses pada tanggal 26 Juli 2019

34 Veri Junaidi. Mahkamah Konstitusi Bukan Mahkamah Kalkulator. (Jakarta: Themis Books, 2013), hlm. 25. 
sebagai suatu konsep tentang nilai dan norma, selalu diperhadapkan pada pilihan dengan demos. Hal ini disebabkan oleh kenyataan bahwa konsep demokrasi juga memiliki keterbatasan atau kelemahan bawaannya tersendiri. Bahkan, jika didasarkan pada jelajah historis awal lahirnya konsep demokrasi pada masa Yunani Kuno, demokrasi dianggap sebagai bentuk pemerintahan yang buruk dan tidak ideal. $^{35}$

Namun di zaman modern sekarang ini, tidak dapat dibantah bahwa konsep demokrasi secara luas dianggap sebagai konsep yang diidealkan dan menjadi pilihan terbaik dari berbagai pilihan yang ada. Bahkan menurut sebuah laporan studi yang disponsori oleh PBB, yakni UNESCO, pada awal 1950-an menyebutkan bahwa tidak ada satupun tanggapan yang menolak demokrasi sebagai landasan dan sistem yang paling tepat bagi semua organisasi politik dan organisasi modern. ${ }^{36}$

Masalah yang belum sampai pada titik temu terkait diskursus demokrasi adalah bagaimana mengimplementasikan demokrasi itu pada praktiknya. Salah satu kelemahan yang sering mengemuka adalah, bahwa sistem demokrasi terlalu mengandalkan diri pada prinsip mayoritas, sebagaimana doktrin "one man onevote".

\footnotetext{
35 Ibid. hlm. 146

36 Nieematul Huda. Hukum Tata Negara Indonesia. (Jakarta: PT. RajaGrafindo Persada, 2005), hlm. 237.
}

Sehingga tidak jarang yang menyejajarkan sistem demokrasi dengan sistemkapitas di dalam dunia bisnis dengan prinsip "one share one vote". Keputusan suara mayoritas menafikan suara minoritas. Padahal, mayoritas bukan jaminan kebenaran dan keadilan.

Menyadari berbagai kelemahan bawaan pada konsep demokrasi ini, maka proses pengambilan keputusan dalam dinamika kekuasaan negara harus diiringi dengan prinsip keadilan, nomokrasi, atau "the rule of law". Inilah yang kemudian disebut oleh Jimly Asshiddiqie sebagai prinsip negara hukum, yang mengutamakan kedaulatan hukum, prinsip supremasi hukum (supremacy of law), atau kekuasaan tertinggi berada di tangan hukum. Dengan demikian, dapat disimpulkan bahwa sistem demokrasi yang diidealkan adalah demokrasi yang didasarkan pada hukum.

Sebab, sebaliknya, negara demokrasi juga dapat berkembang sebagai negara yang chaos dengan sekedar mengembangkan demokrasi sekedar untuk kebebasan tanpa disertai keteraturan dan kepastian hukum. Karena itu, antara ide demokrasi dan nomokrasi tidak untuk diantinomikan sebagai sebuah pilihan. Namun lebih dari itu, harus dipandang sebagai beriringan dan sejalan, sehingga suatu negara itu dapat disebut sebagai negara hukum yang demokratis. Negara hukum yang demikian juga dapat disebut dengan istilah 
"democratsiche rechtsstaat" dan negara demokrasi yang demikian disebut sebagai "constitutional democracy". ${ }^{37}$ Pada pokonya, keduanya merupakan dua sisi dari mata uang yang sama.

Secara etimologis, istilah politik hukum merupakan terjemahan dari istilah hukum Belanda "rechtspolitiek", yang merupakan gabungan dari dua suku kata, yaitu "recht" dan "politiek". Dalam bahasa Indonesia, kata "recht” berarti hukum. Kata “politiek" dalam kamus bahasa Belanda yang ditulis oleh Van der Tas mengandung arti "beleid". Kata "beleid" dalam bahasa Indonesia berarti kebijaksanaan. Jadi secara etimologi, politik hukum berarti kebijaksanaan hukum. ${ }^{38}$

Moh. Mahfud M.D., dalam bukunya "Politik Hukum di Indonesia",39 menyatakan pandangannya tentang politik hukum, bahwa politik hukum adalah:

Legal policy atau garis (kebijakan) resmi tentang hukum yang akandiberlakukan baik dengan pembuatan hukum baru maupun dengan penggantian hukum lama, dalam rangka mencapai tujuan negara.

Dengan demikian, politik hukum menurutnya, merupakan pilihan tentang

37 Ibid. hlm. 146.

38 Imam Syaukani dan A. Ahsin Thohari. Dasar-Dasar Politik Hukum. (Jakarta : PT. RajaGrafinfo Persada, 2007), hlm.12-25

39 Moh. Mahfud M.D. Politik Hukum di Indonesia. Edisi Revisi. Cetakan Keempat. (Jakarta: Rajawali Press, 2011), hlm hukum-hukum yang akan diberlakukan sekaligus pilihan tentang hukum-hukum yang akan dicabut atau tidak diberlakukan yang kesemuanya dimaksudkan untuk mencapai tujuan negara seperti yang tercantum di dalam pembukaan UUD NRI 1945.

Sementara Otong Rosadi dan Andi Desmon, ${ }^{40}$ memandang bahwa istilah politik hukum merupakan terjemahan dari politics of law atau politics of the legalsystem, karena menurutnya, studi politik hukum jangkauannya sangat luas hinggamenyentuh persoalan tatanan atau sistem hukum. Politik hukum adalah proses pembentukan dan pelaksanaan sistem atau tatanan hukum yang mengatur kehidupan masyarakat dalam negara secara nasional. Jadi pengertian politik hukum tidak hanya mengandung makna pembentukan hukum melalui pembentukan peraturan perundangundangan (legal substance) sebagaimana yang dipahami selama ini, namun juga dalam arti penguatan para penegak hukum dan sarana penegakan hukum (legal structure) serta pembangunan budaya hukum (legal culture).

Secara terminologi, pengertian politik hukum dapat dikaji dari dua model pendekatan: Pertama, politik hukum dapat dipahami dengan pendekatan memberikan

40 Otong Rosadi dan Andi Desmon, Studi Politik Hukum; Suatu Optik Ilmu Hukum, (Yogyakarta: Thafa Media, 2012), hlm.3. 
masing-masing pengertian kata "politik" dan "hukum" (divergen) lalu menggabungkan kedua istilah itu (konvergen); Kedua, pendekatan yang langsung mengartikan dalam satu napas (satu kesatuan) sebagai satu frase yang mempunyai pengertian yang utuh. Sebagai satu frase yang mempunyai pengertian yang utuh, frase politik hukum mengandung makna lebih luas dari kebijaksanaan hukum, pembentukan hukum, dan penegakan hukum. Artinya, sebagai satu frase, pengertian politik hukum merupakan keseluruhan aktivitas sebagaimana dimaksud.

Bagir Manan memiliki pandangan bahwa tiada negara tanpa politik hukum. Politik hukum suatu negara terdiri dari politik hukum yang permanen yaitu sikap hukum yang akan selalu menjadi dasar kebijaksanaan pembentukandan penegakan hukum, dan politik hukum yang temporer yaitu kebijaksanaan yang ditetapkan dari waktu ke waktu sesuai dengan kebutuhan. ${ }^{41}$

Lebih lanjut, Bagir Manan menambahkan bahwa politik hukum tidak terlepas dari kebijaksanaan di bidang lain. Penyusunan politik hukum, harus

\footnotetext{
${ }^{41}$ Bagir Manan, Politik Hukum Otonomi Sepanjang Peraturan PerundangUndanganPemerintahan Daerah. Dalam Martin H. Hutabarat, et al (penyunting), Hukum dan Politik Indonesia; Tinjauan Analisis Dekrit Presiden dan Otonomi Daerah, (Jakarta: Pustaka SinarHarapan, 1996), hlm. 144.
}

diusahakan selalu seiring dengan aspekaspek kebijaksanaan di bidang lainnya seperti bidang ekonomi, politik, sosial dan lain sebagainya. Namun demikian, setidaktidaknya ada dua lingkup utama politik hukum, yakni:

a) Politik Pembentukan Hukum, yaitu kebijaksanaan yang bersangkutan dengan penciptaan, pembaharuan dan pengembangan hukum. Politik pembentukan hukum mencakup: Kebijaksanaan (pembentukan) perundang-undangan;

Kebijaksanaan (pembentukan) hukum yurisprudensi atau keputusan hakim; dan c) Kebijaksanaan terhadap peraturan tidak tertulis lainnya.

b) Politik pelaksanaan hukum yaitu kebijaksanaan yang berhubungan dengan kebijaksanaan di bidang peradilan dan kebijaksanaan dibidang pelayanan hukum. ${ }^{42}$ Oleh karena itu, menurut Bagir Manan, di antara kedua aspek politik hukum tersebut hanya sekedar dibedakan, tetapi tidak dapat dipisahkan.

Berbagai definisi tersebut di atas mengantarkan pemahaman pada kita bahwa studi politik hukum mencakup legal policy (sebagai kebijakan resmi negara) tentang hukum yang akan diberlakukan atau tidak diberlakukan dan hal-hal lain yang terkait

42 Ibid., hlm. 145. 
dengan itu. Jadi ada perbedaan cakupan antara politik hukum dan studi politik hukum, yang pertama lebih bersifat formal dan yang kedua mencakup kebijakan resmi dan hal-hal lain yang tercakup dengannya.

Dengan demikian, studi politik hukum mencakup tiga hal: Pertama, kebijakan negara (garis resmi) tentang hukum yang akan diberlakukan atau tidak diberlakukan dalam rangka pencapaian tujuan negara; Kedua, latar belakang politik, ekonomi, sosial, budaya (poleksosbud) atas lahirnya produk hukum; dan Ketiga, penegakan hukum di dalam kenyataan lapangan. ${ }^{43}$

Persyaratan Calon Presiden dan Calon Wakil Presiden Menurut UUD 1945 s/d 1949

Periode 18 Agustus 1945 - 15 Agustus 1950 adalah periode berlakunya konstitusi yang disahkan oleh (PPKI) pada tanggal 18 Agustus 1945, yang kelak kemudian disebut sebagai UUD 1945. Periode ini dibagi lagi menjadi dua masa yaitu, pertama, antara 18 Agustus 1945 - 27 Desember 1949 saat negara Indonesia berdiri sendiri, dan kedua antara 27 Desember 1949 - 15 Agustus 1950 saat negara Indonesia bergabung sebagai negara bagian dari negara federasi Republik Indonesia Serikat. $^{44}$

\footnotetext{
43 Moh. Mahfud. M.D. hlm. 4.

44 Dikutip dari http://ilmutempat34.blogspot.com tentang Sejarah
}

Menurut UUD 1945, lembaga kepresidenan, yang bersifat personal dalam artian bukan merupakan suatu kolektivitas, terdiri atas seorang presiden dan seorang wakil presiden. Lembaga ini dipilih oleh Majelis Permusyawaratan Rakyat (MPR) dengan syarat tertentu dan memiliki masa jabatan selama 5 Tahun. Sebelum menjalankan tugasnya lembaga ini bersumpah di hadapan MPR atau Dewan Perwakilan Rakyat (DPR). ${ }^{45}$

Menurut UUD 1945

1. Presiden memegang kekuasaan pemerintahan

2. Presiden dibantu oleh satu orang wakil presiden

3. Wakil presiden menggantikan presiden jika presiden mangkat, berhenti, atau tidak dapat melakukan kewajibannya dalam masa jabatannya

4. Presiden menetapkan peraturan pemerintah

5. Presiden dibantu oleh menteri

6. Presiden dapat meminta pertimbangan kepada DPA

7. Presiden memegang kekuasaan tertinggi atas Tentara Nasional Indonesia

8. Presiden menyatakan perang dan membuat perdamaian serta

Indonesia Periode 1945 - 1949 diakses pada tanggal 26 Juli 2019.

45 UUD 1945 
perjanjian dengan negara lain atas persetujuan DPR

9. Presiden menyatakan keadaan bahaya

10. Presiden mengangkat dan menerima misi diplomatik

11. Presiden memberi grasi, amnesti, abolisi, dan rehabilitasi

12. Presiden memberi gelar dan tanda kehormatan

13. Presiden memegang kekuasaan membentuk Undang-Undang dengan persetujuan DPR

14. Presiden berhak memveto RUU dari DPR

15. Presiden berhak mengeluarkan peraturan pemerintah pengganti undang-undang dalam keadaan mendesak.

\section{PENUTUP}

Berdasarkan uraian dalam bab-bab sebelumnya, disimpulkan bahwa :

Mengenai konstitusionalitas persyaratan pencalonan Presiden dan Wakil Presiden dalam pemilu serentak, penulis berkesimpulan bahwa secara redaksional kata demi kata dalam Pasal 6 UUD NRI Tahun 1945 secara substansial sangatlah bagus untuk peningkatan kinerja dan hal perekrutan calon presiden di Negara Republik Indonesia. Namun, dengan menghilangkan redaksi kata "Presiden adalah Orang Indonesia Asli” sebagaimana
Pasal 6 UUD 1945 sebelum amandemen sangat lah naif sebab kata-kata yang dimaksud adalah pernyataan bahwa calon presiden dan calon wakil presiden terkait murni sebagai ras indonesia ataupun pribumi asli Indonesia.

Merujuk pada Pasal 6 ayat 1 UUD NRI Tahun 1945 yang hanya mensyaratkan calon presiden dan calon wakil presiden hanyalah seorang WNI dari kelahirannya dapat membuka peluang ras asing yang memperoleh kewarganegaraan dari kelahirannya menuju kursi kepresidenan di Republik Indonesia.

\section{DAFTAR PUSTAKA}

A George Sabine, History of Political Theory,George G.Harrap \& CO.Ltd..London. (Jakarta : Rineka, 2005)..

A. Hamid A. Attamimi, Peranan Keputusan Presiden Republik Indonesia dalam Penyelenggaraan Pemerintahan Negara; Suatu Studi Analisis Mengenai Keputusan Presiden yang Berfungsi Pengaturan dalam Kurun Waktu Pelita I-Pelita IV, Disertasi Ilmu Hukum Fakultas Pascasarjana Universitas Indonesia, Jakarta, 1990.

Bagir Manan, Perkembangan UUD 1945, FH . UII Press, Jogyakarta Politik Hukum Otonomi

Sepanjang Peraturan PerundangUndangan Pemerintahan Daerah. Dalam Martin H. Hutabarat, et al (penyunting), Hukum dan Politik Indonesia; Tinjauan Analisis Dekrit 
Presiden dan Otonomi Daerah, (Jakarta: Pustaka Sinar Harapan, 1996).

Dadang Kahmad. Metode Penelitian Agama, (Bandung : Pustaka Setia. 2000). Hans Kalsen, Teori Hukum Mwni (DasarDasar Ilmu Hukum Normatif Sebagai Ilmu Hukum EmpirikDeskriptif.dilerjemahan oleh Somardi Ahli Bahasa , Rimdjpress (Jakarta : Rineka, 2009). , General Theory Law and State, New Work, Russell and Russell, 1944.

HLA Hart, Konsep Hukum (The Concept of Law). (Penerbit : Nusamedia Tahun 2013).

Imam Syaukani dan A. Ahsin

Thohari. Dasar-Dasar Politik

Hukum. (Jakarta : PT. RajaGrafinfo Persada, 2007).

Jimly Asshiddiqie, 1994, Gagasan Kedaulatan Rakyat dalam Konstitusi dan Pelaksanaannya di Indoensia (Pergeseran keseimbangan antara Individualisme dan kolektivisme dalam kebijakan Demokrasi Politik dan Demokrasi Ekonomi selama Tiga Masa Demokrasi, 19451980-an), cet. I, Jakarta, PT. Ichtiar Baru van Hoeve.

Moh. Mahfud M.D. Politik Hukum di Indonesia. Edisi Revisi. Cet. IV, (Jakarta: Rajawali Press, 2011).

Niecmatul Huda, Hukum Tata Negara Indonesia. (Jakarta: PT. RajaGrafindo Persada, 2005).

Otong Rosadi dan Andi Desmon, Studi Politik Hukum; Suatu Optik Ilmu Hukum, (Yogyakarta: Thafa Media.

Veri Junaidi. Mahkamah Konstitusi Bukan Mahkamah Kalkulator. (Jakarta: Themis Books, 2013).

Yohanis Anton Raharusun. Daerah Khusus Dalam Perspektif NKRI (Telaah Yuridis
Terhadap Otonomi Khusus Bagi Provinsi Papua). (Jakarta: Konstitusi Press, 2009). 